\title{
Dažniausių mimiką
}

simbolizuojančiu jausmaženklių funkcijos lietuviškame tekste

\section{Functions of the Most Frequent Emoticons in the Lithuanian Text}

SAL $30 / 2017$

Dažniausių mimiką simbolizuojančiu jausmaženklių funkcijos lietuviškame tekste

Received 03/2017 Accepted 05/2017

\section{LINGUISTICS / KALBOTYRA}

\section{Regina Sabonytè}

Magistrantè, Vytauto Didžiojo universitetas, Lietuva.

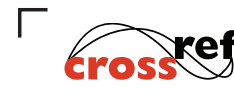

http://dx.doi.org/10.5755/j01.sal.0.30.17705

Jausmaženkliai - naudingas rašytinio teksto prasmès papildymo būdas, padedantis perteikti neverbalinę informaciją. Lietuvių lingvistai kol kas nèra išsamiai analizavę jausmaženkliu vartosenos. Tyrimo tikslas - nustatyti interneto diskusijose dažniausiai vartojamus jausmaženklius ir apibrěžti ju funkcijas tekste. Tyrimo medžiagą sudaro 450 jvairaus ilgio interneto komentaru, kurie surinkti iš interneto forumo Draugas.lt, ju tekstai rašyti 2010-2015 m. Komentarai rinkti iš diskusiju apie ligas, mitybą, kiną, religiją, dvasingumą, studijas, sportą, automobilius, kompiuterinius žaidimus, finansus. Kiekvienos temos bendras tekstu ilgis - 1300-1600 žodžių. Jausmaženklių funkcijoms analizuoti pasitelktas tekstynų lingvistikos metodas.

Nustatyta, kad dažniausiai interneto forumo diskusijose vartoti šeši jausmaženkliai: :), :D, ;), :P, :/ ir :(. Jie gali: a) sustiprinti arba pakartoti žodinès informacijos emocini turini; b) nurodyti rašančiojo požiūri ar vertinimą, kuri be jausmaženklių adresatui būtų sudètinga identifikuoti; c) atlikti sakinio pabaigos skyrybos ženklų funkcijas. Jausmaženkliai ;) ir :) yra platesnès reikšmės, todèl jiems galima priskirti ir daugiau funkcijų: šie jausmaženkliai dažnai vartojami su mandagumo frazėmis, padeda užmegzti ryši su kitais diskusijos dalyviais, sušvelnina neigiamą informaciją.

REIKŠMINIAI ŽODŽIAI: jausmaženkliai, jausmaženklių funkcijos, elektroninè komunikacija, interneto forumas, interneto dikskusijos.

Vis intensyvejjant ir techniškai tobulejjant elektroninei komunikacijai, atsiranda naujų neverbalinės informacijos raiškos galimybiu ir priemonių tekste. Jausmaženkliai - grafiniai simboliai ar ju deriniai, skirti emocijoms ir vertinimui reikšti, yra vienas iš būdu, pasitelkiamu tokiai informacijai perteikti bendraujant trumposiomis žinutemis telefonu ar socialiniuose tinkluose, susirašinejant elektroniniais laiškais, diskutuojant interneto forumuose ir t. t.

Kitaip nei paralingvistiniai elementai, jausmaženkliai i tekstą jterpiami sąmoningai (Crystal, 2004, p.34) ir kalbos vartotojai juos pripažista kaip naudingus rašytinio teksto prasmès papildymo būdus (Žalkauskaitè, 2012, p.147). Remiantis jausmaženkliu vartosena gali būti nustatoma, pavyzdžiui, socialinių tinklų ar interneto puslapių lankytojų emocinè būsena (Settanni, Marengo, 2015) arba jausmaženkliu vartosenos jtaka deryboms ir darbui internetu (Gettinger, Koeszegi, 2015; Lour ir kt., 2010). Todel tokie tyrimai gana plačiai pritaikomi ir ak-

\section{Ivadas}

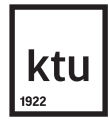

Research Journal Studies about Languages No. $30 / 2017$ ISSN 1648-2824 (print) ISSN 2029-7203 (online) pp. 5-17

DOI 10.5755/j01.sal.0.30.17705 (c) Kaunas University of Technology 
tualūs. Visgi lietuvių lingvistų darbuose (Ryklienè, 2001, Žalkauskaitè, 2012) jausmaženkliu vartosena aptariama tik fragmentiškai, t. y. jausmaženklių funkcijos tekste nèra ju tyrimo objektas. Čia daugiau dèmesio skiriama jausmaženkliams kaip emociju raiškos priemonei arba jausmaženklių sąsajoms su idiolektu apibūdinti. Todèl išsamesnè jausmaženklių vartosenos analizè yra nauja ir aktuali.

Šio tyrimo tikslas - nustatyti interneto diskusijose dažniausiai vartojamus jausmaženklius ir apibrěžti ju funkcijas tekste. Lietuvių lingvistu darbuose nèra vienos nuomonès dèl jausmaženkliu reiškinio terminijos, todèl, siekiant igyvendinti ši tikslą, pirmiausiai išanalizuotos jausmaženklio sąvokos apibrěžtys, aptarti šiam reiškiniui j̇vardyti siūlomi terminai ir aktualiausi jausmaženkliu vartosenos tyrimai (žr. skyrius Jausmaženklio terminas ir Jausmaženkliu funkciju tyrimai). Tyrimui pasirinkta forumo Draugas.lt medžiaga (15110 žodžiu tekstynas, sudarytas iš komentaru), nes: a) šiame forume diskutuojama įvairiomis temomis, todèl diskusijose dalyvauja ir vyrai, ir moterys, b) diskusiju turinys viešai prieinamas, komentarai gana išsamūs; c) forume saugomos kelerių metų laikotarpio diskusijos. Forumo medžiagos pagrindu sudarytas tekstynas, kuriuo remiantis nustatyta, kiek ir kokiu jausmaženklių vartojama komentaruose, išanalizuoti dažniausių mimiką reiškiančiu jausmaženklių vartosenos dèsningumai bei apibrèžtos ju funkcijos tekste (žr. skyrių Mimikq simbolizuojančiu jausmaženliu vartosena ir funkcijos).

\section{Jausmaženklio terminas}

Nors jausmaženkliai rašytiniame diskurse atsirado maždaug prieš tris dešimtmečius, i lietuvių kalbą terminas jausmaženklis atejo gana neseniai - kol kas šis reiškinys ir jo pavadinimas neitrauktas nei i Dabartinès lietuvių kalbos žodyną, nei i Lietuvių kalbos žodyną ar Bendrinès lietuvių kalbos žodyną, o Lietuvių kalbos naujažodžių duomenynui ji pateikta 2012 m. Čia jausmaženklis apibrèžiamas kaip elektroninèje komunikacijoje (trumposiose telefono žinutèse, el. laiškuose, interneto forumuose ir pan.) vartojamas grafinis ženklas ar ju derinys jvairiems jausmams reikšti (apibrèžtis atnaujinta 2015 m.). Kiti kalboje paplitę jausmaženklio sinonimai - svetimybės emotikonas, smailas ir žodžiai šypsenèlé, veidukas, šypsniukas. Enciklopediniame kompiuterijos žodyne jausmaženkliai vadinami jaustukais, tačiau tokias ženklų kombinacijas vadinti jaustukais netikslu ir neparanku (ypač aprašant lingvistikos tyrimus, plg. Miliūnaitè, 2008, p.44), nes jaustukas reiškia vieną iš kalbos dalių.

Iš lietuvių lingvistų darbų, kuriuose, nors ir fragmentiškai, aprašoma jausmaženklių vartosena, minètini du - Astos Ryklienès disertacija Elektroninis diskursas: kalbos ypatybès ir stilius (2001) ir Gintarès Žalkauskaitès disertacija Idiolekto požymiai elektroniniuose laiškuose (2012). Šiuose darbuose taip pat nèra vienos nuomonès dèl jausmaženkliu terminų. Ryklienès disertacijoje, kur tyrinèti interneto naujienu grupių elektroniniai laiškai, terminas jausmaženklis neminimas. Pažymima, kad emocijoms reikšti elektroniniame diskurse vartojamos iprastiniu skyrybos ir kitokiu ženklu kombinacijos, sudèliotos taip, kad vaizduotu veidą. Specialieji emocijas rodantys ženklai neretai vadinami šypsniukais, nors gali vaizduoti ne tik besišypsanti, bet ir kitokios nuotaikos veidą (Ryklienè, 2001, p.88).

Maždaug dešimtmečiu vèliau parengtoje Žalkauskaitės disertacijoje terminas jausmaženklis vartojamas ir apibrěžiamas išsamiau. Anot Žalkauskaitès (2012, p.147), jausmaženkliai yra emocijas reiškiančios skyrybos ir kitu ženklu kombinacijos, skirtos perduoti neverbalinę informaciją, dažniausiai susijusią su veido išraiška, balso tonu arba gestais. Nors Lietuvių kalbos naujažodžiu duomenyne apibrěžiama, kad jausmaženkliai vartojami elektronineje komunikacijoje, tačiau Žalkauskaitè (2012, p.147) pažymi, jog šis elektroniniame diskurse ¡sigalejjęs grafikos reiškinys plinta ir i kitus kalbos sluoksnius - buitinio stiliaus kompiuteriu rinktus bei ranka rašytus tekstus. Ji teigia, kad yra skiriamos dvi jausmaženkliu grupès: 
iš skyrybos ženklu sudaryti jausmaženkliai (angl. smileys) ir emociju paveikslèliai, siūlomi kompiuteriniu programu (angl. emoticons) (Barasa, 2010, p.219, cit. Žalkauskaitè, 2012, p.147).

Greičiausiai del to, kad elektroninis diskursas sparčiai plinta ir atsiranda vis nauju jo atmainų, Ryklienės ir Žalkauskaitės pateiktas jausmaženkliu grupių apibrèžtis vertètu patikslinti. Oksfordo internetiniame žodyne galima rasti, kad anglu kalboje: 1) smiley apibrezziamas kaip simbolis, kuris reiškia besišypsanti veidą, dažniausiai sudaromas iš ženklu :-) ir vartojamas norint parodyti, kad rašantysis yra gerai nusiteikęs arba juokauja; 2) emoticon yra iš ivairių rašmenų sudaryta veido išraiška (pavyzdžiui, šypsenos ar susiraukusio veido), elektroniniame bendravime padedanti perteikti rašančiojo jausmus arba frazės toną; 3) emoji - nedidelis skaitmeninis atvaizdas ar piktograma, kuria elektronineje komunikacijoje išreiškiama idèja ar emocijos.

Nors žodžiu smiley, emoticon ir emoji vartosena literatūroje anglu kalba varijuoja, visgi remiantis Oksfordo internetiniame žodyne pateikiamomis apibrěžtimis visų jausmaženkliu, sudarytų iš skyrybos ženklų, greičiausiai nebūtų galima vadinti smiley, nes smiley yra simbolių kompozicija, reiškianti tik besišypsanti veidą. Be to, dabar daugelis kompiuteriniu programu iš skyrybos ženklu rašančiojo sudaromus jausmaženklius automatiškai paverčia emociju paveikslèliais, Žalkauskaitès vadinamais emoticon. Todèl akivaizdu, kad emoticon sąvoka yra platesnè negu smiley: smiley vadinami jausmaženkliai vaizduoja besišypsanti veidą ir yra tik dalis emoticon, o emoticon gali simbolizuoti bet kokią veido išraišką ir atrodyti tiek kaip tam tikra rašmenu kombinacija, tiek kaip nedideli paveikslèliai. Paminètina, jog dabartiniame elektroniniame diskurse šie paveikslèliai gali būti ir animuoti, t. y. judantys.

Žalkauskaitès minimus paveikslèlius, kurie vaizduoja jvairius objektus bei veiksmus ir kuriuos elektronineje komunikacijoje galima jterpti i tekstą (Žalkauskaitè, 2012, p.147), veikiausiai būtu galima pavadinti Oksfordo internetiniame žodyne apibrèžiamais emoji, nes būtent šie 1999 m. japonu sukurti paveikslèliai gali vaizduoti ir kokią nors idèją (objektus ar reiškinius), ir emocijas (veido išraišką ar kūno judesius). Naujažodis emodži 2015 m. itrauktas ir i Lietuvių kalbos naujažodžių duomenyną.

Apibendrinant galima teigti, kad lietuvių kalboje jausmaženkliai apibréžiami kaip emocijas ženklinančios rašmenų kombinacijos ar nedideli paveikslèliai. Šie paveikslèliai gali būti ne tik emoticon, bet ir dalis emodži paveikslèliu, simbolizuojančių mimiką.

Užsienio mokslininkai jausmaženklių vartoseną analizuoja kaip tarpdisciplinini reiškini ir tokie tyrimai dažnai yra taikomojo pobūdžio (Settanni, Marengo, 2015; Gettinger, Koeszegi, 2015). Visgi naujausi darbai atskleidžia, kad analizuojant jausmaženklių vartoseną mokslininkams kyla nemažai keblumu. Davidas Crystalas, aptardamas tendencijas, kaip bendravimas internetu keičia rašytinès kalbos vartoseną (2011, p.28-32), visų pirma pabrěžia, kad labai trūksta išsamių tyrimų apie tai, kas, kada, kur, kodel ir kokius jausmaženklius renkasi vartoti atsižvelgiant i kiekvieną bendravimo internetu būdą, nes skirtingose interneto terpèse skiriasi tiek rašytinès kalbos, tiek jausmaženkliu vartosena. Be to, anot Francisco Yuso (2014, p.1), sudetinga nustatyti, ar jausmaženkliai visuomet pasirenkami apgalvotai arba kiek apgalvotai atliekamas šis veiksmas (atsižvelgiant i šiuolaikinių kompiuteriniu programu siūlomą jausmaženkliu ivairovę, ju pateikimo tvarką programos lange ir pan.). Esama ir kitokių tyrimo procesą sunkinančių veiksnių (Yus, 2014, pp.1-6):

1 Jausmaženkliais tarsi dubliuojamas jau parašytas tekstas. Paraleliai egzistuoja ir iš rašmenu sukomponuoti jausmaženkliai, ir jaus- 
maženkliai-paveikslèliai (kurie gali būti animuoti); skirtingos programos iš rašmenu sudèliotus jausmaženklius paverčia skirtingais paveikslèliais arba vienos programos paveikslèliais juos paverčia, kitos - ne.

3 Skiriasi elektroninio bendravimo pro3 gramų (ir priemonių) siūlomi vartoti jausmaženkliai.

4 Nèra apibrèžta, kuriuos jausmaženklius ju intensyvumą norima perteikti.
5 Iš analizuojamo teksto ne visuomet galima nustatyti jausmaženklio pasirinkimo priežasti.

Jausmaženklių pasirinkimui didelès itakos turi kontekstas ir aplinkybès: ju gausa ir ivairovè gali priklausyti nuo individualaus stiliaus, asmenu, su kuriais bendraujama, diskusijos formalumo lygmens, temu ir pan.

Dèl taikomojo jausmaženkliu vartosenos tyrimu pobūdžio išaugo ir domejjimasis jausmaženkliu funkcijomis tekste: per pastaraji dešimtmeti anglu kalba publikuotuose darbuose galima rasti tiek išsamesnių, tiek ne tokių išsamių bandymų klasifikuoti jausmaženklių funkcijas. Toliau pateikiamos išsamiausios jausmaženklių funkciju klasifikacijos, kurias straipsnio autorei pavyko rasti.

Elis Dresneris ir Susana Herring (2010, p.62) teigia, kad jausmaženkliai tekste: a) ženklina emocijas, perduodamas jausmaženkliu, primenančiu veido išraišką; b) ženklina reikšminę informaciją, nesusijusią su emocijomis, bet sutartinai (tai priklauso nuo bendraujančiu žmonių) žymimą jausmaženkliais, vaizduojančiais mimiką; c) vartojami ilokucinei jejgai (angl. illocutionary force) sustiprinti. Natia Amaghlobeli (2012, pp.352-353) mano, kad jausmaženkliai: a) papildo žinutę neverbaliniais elementais; b) yra perteklinè informacija - antrina tai, kas pasakyta žodžiais; c) paneigia arba anuliuoja žodžiais išreikštą mintij; d) pakeičia teksto minti (atskleidžia tikrają teksto prasmę); e) dažnai vartojami vietoje skyrybos ženklų. Anot Daantje Derks ir jos kolegu (2007, pp.11-12), jausmaženkliai: a) išreiškia emocijas; b) sustiprina (papildo) žodinę informaciją ir c) vartojami išreiškiant humorą. Barry Kavanaghas (2010, pp.75-77) teigia, kad šie ekstralingvistinès informacijos žymikliai: a) vartojami santūrumui reikšti; b) atlieka apsauginę (barjero) funkciją; c) sušvelnina prašymus; d) vartojami kaip viena iš pozityvaus mandagumo strategiju; e) padeda užmegzti ryši; f) išreiškia humorą; g) perteikia emocijas; h) padeda sužadinti ir išreikšti empatiją; i) vartojami vietoje žodžiu. Yusas (2014, p16) nustatè, kad jausmaženkliai tekste: a) nurodo požiūri ar vertinimą, kurio be jausmaženklių adresatas neatpažintų; b) sustiprina žodžiais išreikšto požiūrio ar vertinimo intensyvumą; c) sustiprina arba sušvelnina ịtaigą; d) paneigia žodžiais perduotą informaciją juokaujant; e) paneigia žodžiais perduotą informaciją ironizuojant; f) padeda išreikšti vertinimą ar emocijas, susijusias su pasisakymo turiniu; g) padeda išreikšti vertinimą ar emocijas, susijusias su visu komunikaciniu aktu; h) perduoda žodžiais išreikšto jausmo arba emocijos intensyvumą.

Kaip matyti iš pateiktų klasifikacijų, autoriai vieningai sutaria, kad jausmaženklių funkcijos tekste neapsiriboja vien tik emocijų raiška, kuri dažniausiai akcentuojama apibrežiant jausmaženklio terminą. Tačiau kai kuriais atvejais klasifikacijos persidengia tarpusavyje (pvz., humoro išraiška pasitelkiant jausmaženklius minima tiek Derks, tiek Kavanagho klasifikacijose), o kai kur trūksta tikslumo pačios klasifikacijos viduje. Pavyzdžiui, nèra iki galo aišku, kodèl Kavanaghas skiria dvi skirtingas funkcijas: c) sušvelnina prašymus ir d) vartojami kaip viena iš pozityvaus mandagumo strategijų, nes galètu atrodyti, kad funkcija $c$ tèra vienas iš $d$ funkcijos variantu; taip pat neaišku, kaip Yuso tyrime atpažinta riba tarp juokavimo ir ironijos skiriant dvi atskiras funkcijas: d) paneigia žodžiais perduotą informaciją juokaujant ir e) paneigia žodžiais perduotą informaciją ironizuojant. Taigi ne visos užsienio autorių pateikiamos 
jausmaženkliu funkciju klasifikacijos atrodo tikslios, ne visuomet aiškus funkciju skyrimo pagrindas. Taip pat nèra žinoma, ar šias klasifikacijas būtų galima pritaikyti ir lietuvių kalbai. Todèl atrodo prasminga atlikti jausmaženkliu vartosenos analizę ir išsiaiškinti, kokias funkcijas jausmaženkliai atlieka lietuviškame tekste.

\section{Tyrimo medžiaga ir metodika}

Tyrimo medžiagą sudaro 450 jivairaus ilgio interneto komentaru, kuriuose vartojami jausmaženkliai. Komentarai surinkti iš interneto forumo Draugas.lt, ju tekstai rašyti 2010-2015 m. Komentarai rinkti iš diskusiju apie ligas, mitybą, kiną, religiją, dvasingumą, studijas, sportą, automobilius, kompiuterinius žaidimus, finansus. Stengtasi, kad kiekvienos temos komentaru žodžiu skaičius būtų kiek įmanoma panašesnis (jis svyravo apytiksliai nuo 1300 iki 1600 žodžiu). Komentarus tyrimui nuspręsta rinkti iš interneto forumo, o ne iš socialinių tinklų, pasisakymu po straipsniais ar asmeniniu žinučiu, nes: a) interneto forumuose komentaru autoriai bendrauja anonimiškai, čia kuriamas dialogas, taigi emociju raiška ribojama mažiau nei, pavyzdžiui, viešuose socialiniu tinklu puslapiuose ar komentaruose po straipsniais, kur dialogas beveik nekuriamas; b) iš diskusiju skirtingomis temomis surinkti ¿vairiu autoriu komentarai gali padèti jžvelgti bendresnes, o ne individualias ar kuriai nors nedidelei žmoniu grupei būdingas jausmaženklių vartosenos ypatybes.

Jausmaženklių funkcijoms analizuoti pasitelktas tekstynu lingvistikos metodas - iš komentaru sudarytas 15110 žodžių tekstynas. Interneto forumuose dažniausiai skiriasi jivairiu jausmaženkliu piktografinè raiška, todèl pasirinkta analizuoti komentarus iš vieno interneto forumo, taip siekiant išvengti netikslumu nedidelius jausmaženkliu paveikslèlius pakeičiant rašmenų kombinacijomis1. Iš viso tekstyne užfiksuoti 673 jausmaženkliai ir piktografiniai ženklai2. Apie 30 proc. (198 jausmaženkliai) buvo sudaryti iš rašmenų, o apie 70 proc. (475 jausmaženkliai ir piktografiniai ženklai) - nedideli paveikslèliai, kai kurie iš ju animuoti. Šie duomenys patvirtina Yuso (2014, p.4) teigini, kad, nors anksčiau dauguma veido išraišką vaizduojančių jausmaženkliu būdavo sudaromi iš raidžių ir skyrybos ženklų, dabar juos dažniausiai pakeičia nedideli (animuoti) paveikslèliai. Dalis interneto forumo diskusijose rastu paveikslèliu galejjo būti vartotoju sudaryti iš rašmenu kombinaciju ir veliau kompiuterinès programos automatiškai paversti i paveikslèlius, o kita dalis paveikslèliu rašant komentarus pasirinkti iš kompiuterinès programos lango, tačiau nustatyti, kurie paveikslèliai užrašyti kuriuo būdu, nebuvo imanoma. Todèl šiame tyrime nebus analizuojama, ar jausmaženkliu formatas gali turèti j̇akos ju funkcijoms tekste.

Surinkus tekstyną paveikslèliai pakeisti iš rašmenu sudarytais jausmaženkliais arba kitokiais pakaitos simboliais (žr. 1 lentelę).

Vèliau, siekiant nustatyti vartosenos dèsningumus, naudojantis programa AntConc (versija 3.4.4.0) sudaryti ir analizuoti jausmaženkliu konkordansai. Nuspręsta atskirai neanalizuoti animuotu ir neanimuotu jausmaženkliu vartosenos, nes animuoti jausmaženkliai surinktuose komentaruose pasitaike tik sporadiškai. Todèl, pavyzdžiui, analizuojant besijuokianti veidą žyminčio jausmaženklio :D vartoseną, i jo konkordansą jtraukti ir jvairiomis kryptimis judančios besijuokiančio veidelio animacijos (žr. 1 lentelę, nr. 12) pavartojimo atvejai.

1 Nedidelius jausmaženklių paveikslèlius pakeisti rašmenų kombinacijomis reikalauja tekstynu analizès programos AntConc specifika.

2 Piktografiniais ženklais čia ir toliau vadinami nedideli paveikslèliai, kurie nèra mimiką vaizduojantys jausmaženkliai (pvz., 14 pav. pirmoje lenteleje). 9 ir 10 paveikslèliai pirmoje lentelèje galètų būti iš dalies laikomi ir mimiką vaizduojančiais jausmaženkliais, ir piktografiniais ženklais, nes juose neapsiribojama vien tik mimika. Šiame tyrime jie laikyti jausmaženkliais, nes vaizduoja ir veido išraišką.

Mimika
simbolizuo-
jančių
jausmaženliu
vartosena ir
funkcijos

Mimika simbolizuojančlų jausmaženliu funkcijos 


\begin{tabular}{|c|c|c|c|c|}
\hline \multirow{15}{*}{$\begin{array}{r}1 \text { lentelé } \\
\text { Komentaruose } \\
\text { užfiksuoti paveikslèliai } \\
\text { ir ju pakaitos simboliai } \\
\text { tekstyne }\end{array}$} & $\mathrm{Nr}$. & Paveikslèlis & Paaiškinimas & Pakaitos simboliai tekstyne \\
\hline & 1. & 9 & & :) \\
\hline & 2. & @ & & :D \\
\hline & 3. & 0 & & $: P$ \\
\hline & 4. & $\Theta$ & Merkiančio aki veidelio animacija. & ;) \\
\hline & 5. & 8 & & $:($ \\
\hline & 6. & $\Theta$ & $\begin{array}{l}\text { Išsižiojančio ir išpučiančio akis (nustebusio) } \\
\text { veidelio animacija. }\end{array}$ & :0 \\
\hline & 7. & (9) & & :/ \\
\hline & 8. & (4) & Nuleistos akys (žiūri žemyn). & FACE1 \\
\hline & 9. & (3) & & FACE2 \\
\hline & 10. & (xy & & FACE3 \\
\hline & 11. & 9 & Vartančio akis veidelio animacija. & ANIM1 \\
\hline & 12. & 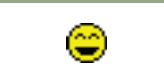 & $\begin{array}{l}\text { Ivairiomis kryptimis judanti besijuokiančio } \\
\text { veidelio animacija. }\end{array}$ & ANIM2 \\
\hline & 13. & (3) & & $>:($ \\
\hline & 14. & 8 & & $\mathrm{PIC1}$ \\
\hline
\end{tabular}

\section{Jausmaženklių vartosenos ir funkcijų analizẻ}

Suskaičiavus visus tiriamojoje medžiagoje užfiksuotus jausmaženklius ir surikiavus juos pagal vartojimo atvejų dažnumą, nustatyta, kad dažniausiai analizuojamose interneto forumo Draugas.lt diskusijose vartojami teigiamas emocijas žymintys jausmaženkliai (žr. 2 lentelę). Dažniausi (46,1 ir 38,1 proc.) yra teigiami jausmaženkliai :) ir :D bei ju variantai, vaizduojantys besišypsanti ar besijuokianti veidą. Teigiamais laikytini ;) ir :P jausmaženkliai vartojami gerokai rečiau (5,7 ir 3,4 proc.) nei minèti :) ir :D. Vis dèlto jie gerokai dažnesni už neigiamas emocijas reiškiančius :/ ir :( (1,8 ir 1,3 proc.). Kitu jausmaženklių pasitaikè nedaug (visi kartu jie sudaro 3,3 proc.). Todèl nuspręsta analizuoti tik 6 dažniausiu jausmaženkliu vartoseną ir funkcijas: :), :D, ;), :P, :/ bei :(.

Kaip jau minèta, tiriamoji medžiaga apima 2010-2015 metus. 2015 metais jausmaženklis, vaizduojantis besijuokianti veidą su džiaugsmo ašaromis (angl. face with tears of joy), Oksfordo žodyno buvo paskelbtas metu žodžiu. ldomu tai, kad tiriamojoje medžiagoje toks jausmaženklis nebuvo pavartotas nei karto. To priežastys galètų būti kelios: 1) šis jausmaženklis 2010-2015 metais Lietuvoje dar nebuvo populiarus; 2) kadangi jausmaženkliu vartosena gali priklausyti nuo interneto terpès, šis jausmaženklis galejo būti vartojamas ne forume Draugas.lt, o kitur (pvz., socialiniuose tinkluose), todèl jo vartosenos pavyzdžiu tiriamojoje medžiagoje ir nepasitaikè; 3) šis jausmaženklis nebuvo itrauktas tarp jausmaženkliu, kuriuos, rašant komentarą forume, galima pasirinkti iš kompiuterinès programos lango.

Renkant tekstyną diskusijose kai kuriomis temomis (pvz., ligos, finansai) tikètasi rasti gerokai daugiau neigiamas emocijas reiškiančių jausmaženklių. Vis dèlto tokiose diskusijose neigiamos emocijos dažniau reiškiamos ne jausmaženkliais, o žodžiais (apie neigiamus dalykus rašoma daugžodžiaujant arba atvirkščiai - labai lakoniškai) ar kitokiomis priemonè- 


\begin{tabular}{|c|c|c|c|c|}
\hline $\begin{array}{l}\text { Nr. pagal } \\
\text { dažnumą }\end{array}$ & $\begin{array}{c}\text { Jausmaženkliu } \\
\text { žymima informacija }\end{array}$ & $\begin{array}{l}\text { Jausmaženklio } \\
\text { variantai komentaruose }\end{array}$ & $\begin{array}{l}\text { Iš viso } \\
\text { vartosenos atveju } \\
\text { tekstyne }\end{array}$ & $\begin{array}{l}\text { Visu tekstyno jausmažen- } \\
\text { klių dalis (proc.) }\end{array}$ \\
\hline 1. & Šypsena & :), $\bigoplus,:-),:],:\},:>$ & 310 & 46,1 \\
\hline 2. & Juokas & 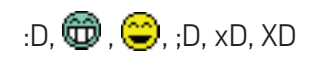 & 256 & 38,1 \\
\hline 3. & Mirksnis & ;), (9) & 38 & 5,7 \\
\hline 4. & Iškištas liežuvis & $P, 8$ & 23 & 3,4 \\
\hline 5. & Susirūpinimas & $: 9$ & 12 & 1,8 \\
\hline 6. & Liūdesys & $:(8$ & 9 & 1,3 \\
\hline 7. & & - & 6 & 0,9 \\
\hline \multirow[t]{3}{*}{8.} & & $: 0, \Theta$ & 3 & 0,4 \\
\hline & & (9) & 3 & 0,4 \\
\hline & & griv & 3 & 0,4 \\
\hline \multirow[t]{3}{*}{9.} & & ; & 2 & 0,3 \\
\hline & & :S & 2 & 0,3 \\
\hline & & $>:()$, & 2 & 0,3 \\
\hline \multirow[t]{3}{*}{10.} & & 0_0 & 1 & 0,1 \\
\hline & & (9) & 1 & 0,1 \\
\hline & & 9 & 1 & 0,1 \\
\hline
\end{tabular}

\section{2 lentelè}

Jausmaženkliu vartojimo atvejų dažnumas ir dažniausių jausmaženklių reikšmès

mis, pavyzdžiui, daugtaškiais.

Siekiant nustatyti jausmaženklių vartosenos dėsningumus ir apibrèžti funkcijas, buvo analizuojami konkordansai. Pastebèta, kad tiek teigiamas, tiek neigiamas emocijas reiškiantys jausmaženkliai rašomi tais atvejais, kai žodžiais taip pat jvardijama teigiama arba neigiama informacija ir (arba) jos vertinimas. Tiek teigiami, tiek neigiami jausmaženkliai taip pat gali būti vartojami juokaujant. Pasitaike ir atveju, kai remiantis žodine informacija konkordanse ne visada buvo galima pasakyti, kodèl po tam tikros frazės vartojamas vienas ar kitas jausmaženklis, t. y. atrodytu, kad jausmaženklio toje vietoje, kur jis parašytas, galètu ir nebūti, tačiau jis visgi rašomas. Remiantis šiomis pastabomis, nuspręsta suskirstyti jausmaženklių vartosenos atvejus ir išsiaiškinti, kurie analizuojamų jausmaženklių dažnumą: a) teigiamame kontekste; b) neigiamame kontekste; c) juokaujant ar ironizuojant; d) kai vartosenos priežastis iš žodinės informacijos ne visai aiški. Pagal teigiamu arba neigiamu jausmaženklių vartoseną teigiamame ar neigiamame kontekste jausmaženkliai galètu patvirtinti (sustiprinti) arba prieštarauti žodžiais pasakytai informacijai. Kadangi aiškias ribas tarp humoro ir ironijos ar sarkazmo nubrěžti sudètinga, nes jos labai priklauso nuo konteksto bei individualios rašančiojo ir skaitančiojo patirties, šiame darbe tokiais atvejais pavartoti jausmaženkliai priskiriami vienai grupei.

Visgi suskirstyti jausmaženklių vartosenos atvejus ị tokias grupes nebuvo paprasta - tai sun- 
kino skirtingi jausmaženkliu perduodamos informacijos intensyvumo raiškos būdai. Emocijos intensyvumui parodyti jausmaženklio dalis, vaizduojanti burną, gali būti rašoma kelis kartus (pvz., :) žymètu šypseną, o :)))) - plačią šypseną) (Ryklienè, 2001, p.89) arba tas pats jausmaženklis gali būti keliskart pakartotas (pvz.4: mano atsakymas: :P:P:P:P:P:P:P:P:P). Taip pat gali būti rašoma keliu jausmaženklių kombinacija, jeigu norima perteikti ne vienu jausmaženkliu žymimą informaciją (pvz.: Geriau ne 11 kart zaisk ta pati o atsisiusk Nauja Starcraft :D:P:) :D). Jausmaženklių seka, kur tas pats jausmaženklis kartojamas kelissyk, šiame tyrime laikyti atskirais jausmaženkliais, o kai kartojama tik burną žyminti dalis - vienu jausmaženkliu. Vienoje sekoje esančių tapačių arba skirtingu jausmaženklių vartojimo kontekstas priskirtas kuriai nors vienai iš minètu keturiu grupių.

Pastebejjus, kad, kaip teigè ir Žalkauskaitè (2012, p.118), jausmaženkliais dažnai baigiami sakiniai, tačiau sakinio pabaigos skyrybos ženklai šalia ju nerašomi, taip pat nuspręsta patikrinti, kaip dažnai jais baigiamos jvairaus ilgio frazès. Diskusijose nepaisyta rašybos ir skyrybos taisyklių, todèl dažnai buvo keblu nustatyti, ar komentaru autorių frazes galima laikyti sakiniais.

Suskirsčius kiekvieno iš analizuotu jausmaženklių vartosenos atvejus pagal kontekstą, nustatyta, kad mažiausiai varijavo (t. y. dominavo kuri nors viena grupè) neigiamu jausmaženklių :/, : ( bei teigiamu jausmaženklių :P, :D vartosena. Labiausiai varijavo teigiamu jausmaženklių :) ir ;) vartosena (žr. 3 lentelę).

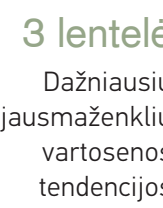

\begin{tabular}{|c|c|c|c|}
\hline \multirow[b]{2}{*}{$\begin{array}{l}\text { Vartosenos } \\
\text { kontekstas }\end{array}$} & \multicolumn{3}{|r|}{ Jausmaženklis } \\
\hline & 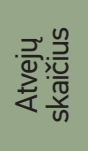 & 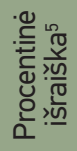 & Vartosenos pavyzdys \\
\hline \multicolumn{4}{|r|}{$:($} \\
\hline Teigiamas & - & - & - \\
\hline Neigiamas & 8 & 89 & $\begin{array}{l}\text { ant pedos. Ziauriai bijau skausmo. eisiu ju naikint i odos dispanseri } \\
\text { (Kaune). labai bijau skausmo:(((()(((()(( }\end{array}$ \\
\hline Juokavimas/ ironija & 1 & 11 & $\begin{array}{l}\text { O mes mat kvaili ir nesuprantam nieko :( O diplominio darbo pirki- } \\
\text { mas nera lygiagretus ir diplomo pirkimui? }\end{array}$ \\
\hline $\begin{array}{l}\text { Vartosenos priežastis ne } \\
\text { visai aiški }\end{array}$ & - & - & - \\
\hline Iš viso & 9 & & \\
\hline \multicolumn{4}{|r|}{ :/ } \\
\hline Teigiamas & - & - & - \\
\hline Neigiamas & 5 & 42 & $\begin{array}{l}\text { oi su nemiga nejuokai :/ pastaruoju metu (apie } 3 \text { savaites) normaliai } \\
\text { negaliu miegot. }\end{array}$ \\
\hline Juokavimas/ ironija & 4 & 33 & “Man tai visi liaudiški metodai nepadeda," kaip netikèta :/ \\
\hline $\begin{array}{l}\text { Vartosenos priežastis ne } \\
\text { visai aiški }\end{array}$ & 3 & 25 & $\begin{array}{l}\text { nevisi kalejime yra nusikaltèliai. bet kažkaip mano žodžius pavertè, } \\
\text { kad sakiau jog būtinai visi :/ }\end{array}$ \\
\hline Iš viso & 12 & & \\
\hline
\end{tabular}

3 Straipsnyje pateikiamų pavyzdžių iš forumo diskusijų originali kalba netaisyta.

4 Apskaičiuojant procentinę išraišką laikyta, kad 100 proc. sudaro visi vieno jausmaženklio vartosenos atvejai. 


\begin{tabular}{|c|c|c|c|}
\hline \multicolumn{4}{|r|}{$: P$} \\
\hline Teigiamas & - & - & - \\
\hline Neigiamas & - & - & - \\
\hline Juokavimas/ ironija & 21 & 91 & $\begin{array}{l}\text { Jezau, biški pakentèsi ir viskas. Grožis reikalauja auku. :D moterims, } \\
\text { juk neskauda :P:P }\end{array}$ \\
\hline $\begin{array}{l}\text { Vartosenos priežastis ne } \\
\text { visai aiški }\end{array}$ & 2 & 9 & Man kai tatuiruotę daré, darytojas stebèjosi kodèl nealpstu :P \\
\hline Iš viso & 23 & & \\
\hline \multicolumn{4}{|r|}{ :D } \\
\hline Teigiamas & 2 & 1 & $\begin{array}{l}\text { Nepamenu kaip ten kas... :) bet pati esmè ta, kad viskas baigési lai- } \\
\text { mingai:D }\end{array}$ \\
\hline Neigiamas & - & - & - \\
\hline Juokavimas/ ironija & 239 & 93 & Jei nualpsi tai nebent iš baimés :D NESKAUDA TEN VISAI. \\
\hline $\begin{array}{l}\text { Vartosenos priežastis ne } \\
\text { visai aiški }\end{array}$ & 15 & 6 & $\begin{array}{l}\text { Šiuo metu ir vell Medal of honor allied assault, turbūt pirmosios dalys } \\
\text { niekad neatsibos :D }\end{array}$ \\
\hline Iš viso & 256 & & \\
\hline \multicolumn{4}{|r|}{;) } \\
\hline Teigiamas & 4 & 10,5 & $\begin{array}{l}\text { ziauriai geras filmas, yra ir pasijuokt is ko, be to, veiksmas tokijuje } \\
\text { vyksta, nu man (b patiko;) }\end{array}$ \\
\hline Neigiamas & 1 & 2,6 & $\begin{array}{l}\text { Bet is esmes tie zaidimai greit nusibosta,nebeleidzia jokiu geru zaidi- } \\
\text { mu, viena diena ir viskas, zaidima galima ant lentynos deti ;) }\end{array}$ \\
\hline Juokavimas/ ironija & 13 & 34,2 & nenumirsit gal be to karantino, žiemos atostogos gi ne už kalnu..;) \\
\hline $\begin{array}{l}\text { Vartosenos priežastis ne } \\
\text { visai aiški }\end{array}$ & 20 & 52,6 & $\begin{array}{l}\text { neblogi Cardiplant, jie sirdies veikla gerina, greita nuovargi, dusuli, } \\
\text { sirdies plakima mazina;) }\end{array}$ \\
\hline Iš viso & 38 & & \\
\hline \multicolumn{4}{|r|}{ :) } \\
\hline Teigiamas & 51 & 16 & pagyvenus, ${ }^{6}$ neitiketinai pralinksminai :]] mano sieloj svente dabar :> \\
\hline Neigiamas & 52 & 17 & $\begin{array}{l}\text { Būtu idomu sužinoti, kodèl toks poelgis, kaip diplominiu pirkimas, } \\
\text { tapo norma mūsu visuomeneje...:) }\end{array}$ \\
\hline Juokavimas/ ironija & 84 & 27 & $\begin{array}{l}\text { Teisingai pastebejai, tai mergelei gripas ne i plaucius, bet i smege- } \\
\text { nine dave. :):) }\end{array}$ \\
\hline $\begin{array}{l}\text { Vartosenos priežastis ne } \\
\text { visai aiški }\end{array}$ & 123 & 40 & $\begin{array}{l}\text { Vienur pigiau, kitur brangiau. Galiausiai nusprendžiau, reikia eti i kli- } \\
\text { nikq, kuria jau išbandžiusi.:) }\end{array}$ \\
\hline Iš viso & 310 & & \\
\hline
\end{tabular}

Kaip matyti iš trečiosios lentelès, jausmaženkliai :/ ir :( dažniausiai (89 ir 42 proc.) vartojami neigiamos (ar neigiamai vertinamos) informacijos kontekste. Jausmaženklis :P (anot Ryklienès (2001, p.89), reiškiantis pašaipą, o, pasak Fullwoodo ir jo kolegu $(2013$, p.26), dažnai vartojamas flirtuojant), kaip ir jausmaženklis :D, turi gana apibrežtą vartojimo kontekstą tiek vienas, tiek kitas dažniausiai (91 ir 93 proc.) vartojami juokaujant ar ironizuojant. ;) ir :) taip pat dažnai (34,2 ir 27 proc.) vartojami juokaujant ar ironizuojant. Be to, jausmaženkli :) linkstama (17 proc.) vartoti teigiamos informacijos kontekste. Vadinasi, galima daryti išvadą, kad, kaip ir parode užsienio tyreju darbai (plg. Yus, 2014, p.1, Amaghlobeli, 2012, p.252), šiame darbe analizuoti jausmaženkliai dažnai pasitelkiami tarsi norint pakartoti ar sustiprinti žodžiais jau pasakytą informaciją.

5 Pagyvenus - forumo diskusijos dalyvio, i kuri kreipiamasi, slapyvardis 
Visu analizuotu jausmaženklių, išskyrus :(, konkordansuose pasitaikè atveju, kai iš žodinės informacijos buvo sudètinga nustatyti jausmaženkliu vartosenos priežastis. Tokius atvejus geriausiai apibendrintu Yuso ivardinta jausmaženkliu funkcija: jausmaženkliai tarsi nurodo rašančiojo požiūri ar vertinimą, kuri norima perteikti žodžiais, tačiau be jausmaženklių adresatui ji būtu sudètinga identifikuoti (Yus, 2014, p.15) arba, kitaip sakant, gali padèti skaitančiajam interpretuoti tai, kas parašyta (Waldner, 2009, p.35 cit. iš Yus, 2014, p.8). Kadangi jausmaženkliu ;) ir :) vartosenoje užfiksuota daugiausiai tokių vartosenos atvejų, analizuojant konkordansus paaiškejjo, kad iš šios funkcijos minètiems jausmaženkliams galima išskirti tarsi dar vieną siauresnę funkciją. Iš visų analizuotu jausmaženklių tik šie du buvo vartojami pasisveikinant (pvz.: Sveiki;) Uždaviau toki retorini klausimq, nes ir pačiq kankinq panašios problemos.), dèkojant (pvz.: Gal zinot kur galima butu Kaune issibalinti ir kokiomis kainomis? Aciu is karto :)), užduodant pirmuosius diskusijos klausimus (pvz.: Idomu butu suzinoti, koki kompiuterini zadima jus siuo metu zaidziate? :) ) ir pan. Taigi būtent šie du jausmaženkliai gali būti vartojami kartu su mandagumo frazėmis ar norint užmegzti ryši (plg. Kavanagh, 2010, pp.75-76). Šias funkcijas atskirti ne visada imanoma, nes kai kuriais atvejais viena frazè gali būti keleriopos paskirties (pvz., Aciu is karto :) gali būti ir padèka, mandagumo išraiška, ir paskatinimas atsakyti i klausimą). Nustatyta, kad visi kartu tokie atvejai sudare 34 proc. jausmaženklio ;) (13 atveju iš 38) ir 16 proc. jausmaženklio :) (50 atveju iš 310) vartosenos pavyzdžių.

Nevienodas jausmaženklių vartosenos atvejų pasiskirstymas tarp minètu grupių (žr. 4 lentelę) rodo, kad, nors egzistuoja funkcijos, kurias tekste gali atlikti visi analizuoti jausmažen-

\begin{tabular}{|c|c|c|c|c|c|}
\hline \multirow{9}{*}{$\begin{array}{r}4 \text { lentelè } \\
\text { Dažniausiu } \\
\text { jausmaženkliụ vartojimo } \\
\text { kontekstas ir procentine } \\
\text { išraiška7 }\end{array}$} & \multirow[b]{2}{*}{ Jausmaženklis } & \multicolumn{4}{|c|}{ Vartosenos kontekstas } \\
\hline & & Teigiamas & Neigiamas & Juokavimas/ ironija & $\begin{array}{l}\text { Vartosenos priežastis } \\
\text { ne visai aiški }\end{array}$ \\
\hline & $:($ & - & 1 & 0,1 & - \\
\hline & $: /$ & - & 0,8 & 0,6 & 0,5 \\
\hline & $: P$ & - & - & 3,2 & 0,3 \\
\hline & :D & 0,3 & - & 36,9 & 2,3 \\
\hline & ;) & 0,6 & 0,1 & 2 & 3 \\
\hline & :) & 7,9 & 8 & 13 & 19 \\
\hline & Iš viso & 8,8 & 9,9 & 55,8 & 25,1 \\
\hline
\end{tabular}

kliai, tačiau kai kurios funkcijos gali skirtis, nes jausmaženklio reikšmè vartosenoje gali būti platesnè arba siauresne. ${ }^{6}$

Iš analizuotų jausmaženklių platesnès reikšmès būtų galima laikyti dažniausiai vartotą teigiamą jausmaženkli :), kuri linkstama vartoti ne tik teigiamame kontekste (7,9 proc. iš visu jausmaženkliu vartosenos pavyzdžių) ar juokaujant (13 proc. iš visu pavyzdžių), bet ir neigiamos (8 proc. iš visų pavyzdžių) informacijos kontekste. Tai galetu rodyti dar vieną šio jausmaženklio funkciją - sušvelninti neigiamą informaciją (Žalkauskaite, 2012, p.148; Kavanagh, 2010, p.75, kur teigiama, kad jausmaženkliai vartojami kokiai nors informacijai sušvelninti, tačiau nepatikslinama, kurie jausmaženkliai šią funkciją atlieka).

6 Apskaičiuojant procentinę išraišką laikyta, kad 100 proc. sudaro 648 visų analizuojamu jausmaženklių vartosenos atvejai. 
Taip pat nustatyta tendencija kiekvieną iš analizuotu jausmaženklių vartoti frazės pabaigoje, šalia nerašant sakinio pabaigą rodančiu ženklų. Iš visu jausmaženklio :/ vartosenos atveju tokiu buvo 75 proc., : ( - 78 proc., :P - 91 proc., :D - 76 proc., ;) - 74 proc., :) - 79 proc. Tai leidžia manyti, jog, atlikdami kitas funkcijas, analizuoti jausmaženkliai kartu gali atlikti ir sakinio pabaigos skyrybos ženklų funkcijas. Ši išvada šiek tiek skirtųsi nuo pateikiamu Žalkauskaites ir Amaghlobeli darbuose - čia teigiama, kad jausmaženkliai dažnai atlieka ne sakinio pabaigos skyrybos ženklų, o skyrybos ženklų funkcijas apskritai (plg. Žalkauskaitè, 2012, p.118; Amaghlobeli, 2012, p.352).

Analizuotu jausmaženkliu funkcijas tekste apibendrintai būtų galima pavaizduoti pirmame paveiksle pateikta schema (žr. 1 pav.).

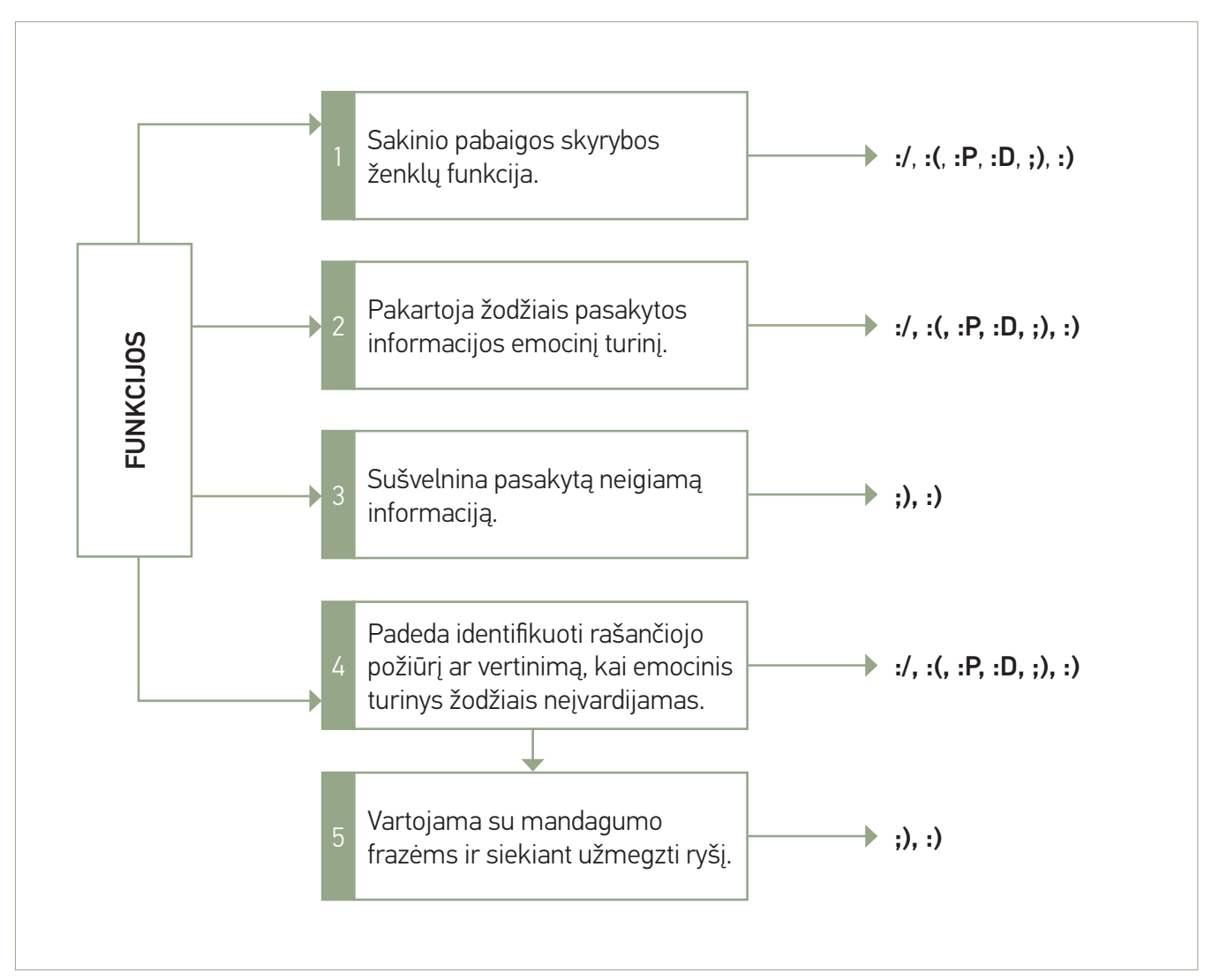

Kaip galima matyti iš pirmojo paveikslo, egzistuoja funkcijos, būdingos visiems šešiems arba daugumai analizuotu jausmaženklių. Tačiau, jeigu jausmaženklio reikšmé vartosenoje platesnè, jis gali atlikti daugiau funkcijų nei siauresnès reikšmés jausmaženkliai.

Išanalizavus dažniausiai interneto forumo Draugas.lt komentaruose rastu jausmaženkliu :), :D, ;), :P, :/ ir :( vartoseną, galima daryti tokias išvadas:

1 Jausmaženkliai dažniausiai pakartoja informaciją, kuri jau buvo ivardinta žodžiais, todèl galima teigti, jog viena iš ju funkciju - sustiprinti arba pakartoti pasakytos informacijos emocini turini.

2

Visi jausmaženkliai, išskyrus :(, vartoti ir tada, kai iš žodinės informacijos buvo sudetinga nustatyti ju vartosenos priežastis. Tokiais atvejais jausmaženkliai skaitančiajam nurodo
1 pav

Dažniausių mimiką žyminčių jausmaženklių funkcijos 
rašančiojo požiūri ar vertinimą, kurį be jausmaženklių adresatui būtu sudètinga identifikuoti.

3 Jausmaženkliams ;) ir :) galima priskirti vieną siauresnę funkciją: jie dažnai vartojami 3 kartu su mandagumo frazèmis ir padeda užmegzti ryši su diskusijų dalyviais.

Dažniausiai vartotas teigiamas jausmaženklis :) yra platesnès reikšmès, nes ji linksta4 ma vartoti ne tik teigiamos, bet ir neigiamos informacijos kontekste. Taigi jis atlieka dar vieną funkciją - sušvelnina neigiamą informaciją.

5 Visus analizuotus jausmaženklius būdinga vartoti jvairaus ilgio frazių pabaigoje, šalia ne$\checkmark$ rašant jokiu skyrybos ženklų. Vadinasi, jie gali atlikti ir sakinio pabaigos skyrybos ženklu funkcijas.

Jausmaženklių funkciju tyrimą būtu galima tęsti analizuojant platesnès reikšmės jausmaženklių vartoseną - greičiausiai būtų galima nustatyti ir daugiau funkcijų negu aptarta šiame darbe. Nors jausmaženkliu išvaizda skirtingose skaitmeninėse terpėse gali būti nevienoda, tikètina, kad, pavyzdžiui, pozityvus jausmaženklis :), kaip ir negatyvus :(, turètu jiems būdingą vartosenos kontekstą ir funkcijas ivairiose skaitmeninėse terpėse.

\section{Literatūra}

1. Amaghlobeli, N., 2012. Linguistic Features of Typographic Emoticons in SMS Discourse. Theory and Practice in Language Studies, 2, Finland: Academy Publisher, pp.348-354.

2. Barasa, S. N., 2010. Language, Mobile Phones and Internet: A Study of SMS Texting, Email, IM and SNS Chats in Computer Mediated Communication (CMC) in Kenya. Daktaro disertacija. Leidenas: Leideno universitetas. Prieiga per internetą: https://openaccess. leidenuniv.nl/bitstream/handle/1887/16136/ Language\%2c\%20Mobile\%20Phones\%20 and\%20Internet\%20Communication. pdf?sequence=1 [žiūrèta 2017-05-15].

3. Crystal, D., 2004. Language and the Internet. Cambridge: Cambridge University Press.

4. Crystal, D., 2011. Internet Linguistics: A Student Guide. London and New York: Routledge.

5. Derks, D., Fischer, A. H., Bos, A. E. R., 2007. The Role of Emotion in Computermediated Communication: A Review. Computers in Human Behavior. Prieiga per internetą: https://www.researchgate.net/ publication/222428783_The_role_of_emotion_ in_computer-mediated_communication_A_ review [žiūrèta 2016-07-13].

6. Dresner, E., Herring, S. C., 2010. Functions of the Non-verbal in CMC: Emoticons and Illocutionary Force. Communication Theory,
3, pp.249-268. https://doi.org/10.1111/

j.1468-2885.2010.01362.x

7. Fullwood, C., Orchard, L., Floyd, S., 2013.

Emoticon Convergence in Internet Chat Rooms. Social Semiotics 23(5), pp.648-662. https://doi. org/10.1080/10350330.2012.739000

8. Gettinger, J., Koeszegi, S. T., 2015: More than Words: The Effect of Emoticons in Electronic Negotiations. In: Kaminski, B., Kersten, G., Szapiro, T. (sud.). Outlooks and Insights on Group Decision and Negotiation. Lecture Notes in Business Information Processing. Springer, Springer International Publishing Switzerland, pp.289-305.

9. Yus, F., 2014. Not All Emoticons are Created Equal. Prieiga per internetą: http://www. researchgate.net/publication/261615359 [žiūrèta 2015-12-01].

10. Kavanagh, B., 2010. A Cross-cultural Analysis of Japanese and English Nonverbal Online Communication: The Use of Emoticons in Weblogs. Intercultural Communication Studies, 3, pp.65-80.

11. Lour, T., Wu, L., Lu, H. P., Tao, Y. H., 2010. The Effect of Emoticons in Simplex and Complex Task-oriented Communication: An Empirical Study of Instant Messaging. Computers in Human Behavior, 26, pp.889-895. https:// doi.org/10.1016/j.chb.2010.02.003 
12. Miliūnaitè, R., 2008. Pirmas žvilgsnis i tinklaraščių kalbą. Kalbos kultūra, 81, pp.1-22.

13. Ryklienè, A., 2001. Elektroninis diskursas: kalbos ypatybés ir stilius. Daktaro disertacija. Vilnius: Lietuvių kalbos institutas.

14. Settanni, M., Marengo, D., 2015. Sharing Feelings Online: Studying Emotional Wellbeing via Automated Text Analysis of Facebook Posts. Prieiga per internetą: http:// journal.frontiersin.org/article/10.3389/ fpsyg.2015.01045/full [žiūrèta 2016-07-13].

15. Žalkauskaitè, G., 2012. Idiolekto požymiai elektroniniuose laiškuose. Daktaro disertacija. Vilnius: Vilniaus universitetas.
Šaltiniai

1. Bendrinés lietuvių kalbos žodynas. Prieiga per internetą: http://bkz.lki.lt [žiūrèta 2016-07-13].

2. Dabartinés lietuvių kalbos žodynas. Prieiga per internetą: http://lkiis.lki.lt/dabartinis [žiūrèta 2016-07-13].

3. Enciklopedinis kompiuterijos žodynas. Prieiga per internetą: http://ims.mii.lt/EK\%C5\%BD/ index.html [žiūrèta 2016-07-13].

4. Lietuvių kalbos naujažodžiu duomenynas. Prieiga per internetą: http://naujazodziai.lki. lt/ [žiūrèta 2015-11-07].

5. Oksfordo internetinis žodynas. Prieiga per internetą: http://www.oxforddictionaries. com [žiūrèta 2015-11-07].

\section{Regina Sabonytè. Functions of the Most Frequent Emoticons in the Lithuanian Text}

Emoticons are considered to be a useful way to express non-verbal information in electronic discourse. However, detailed analysis of the usage of emoticons has not been done by Lithuanian linguists so far. The aim of the research is to identify emoticons that are used in internet discussions most frequently and to determine their functions in a text. The research material consists of 450 comments from the internet forum Draugas.lt, all comments were written during the period of the year 2010-2015. Comments were taken from the discussions about diseases, nutrition, movies, religion, spirituality, studies, sports, cars, computer games, finances. The overall length of the texts of each topic is 1300-1600 words. The method of the research is corpus linguistics.

The analysis of comments revealed that there are six emoticons used in internet discussions most frequently: :), :D, ;), :P, :/ and :(. They can: a) strengthen or repeat emotional content of written information; b) reveal writer's attitude or evaluation of written information which could be difficult to identify without emoticons; $c$ ) function as markers at the end of sentence. Emoticons ;) and :) have wider meaning: they can also be used with phrases of politeness or help to connect with other participants of discussion as well as soften negative information.

\section{Regina Sabonytë}

Magistrantè (Taikomosios lietuvių kalbotyros), Vytauto Didžiojo universitetas.

\section{Mokslinių tyrimų sritis}

Paralingvistinių ir ekstralingvistinių kalbos reiškinių analizè.

\section{Adresas}

V. Putvinskio g. 23-204, LT-44243 Kaunas.

\section{El. paštas:}

reginasab@gmail.com 